\title{
Physical Education - Active Support of the Stage Movement (The Training of the Bodily Expression)
}

\author{
Ana-Cristina LEȘE${ }^{1}$
}

\begin{abstract}
The teaching discipline entitled the Training of the body expression sums those activities that imply the body and which come in varied forms, both as motor structures and as functional features. In the following, we will try to bring arguments in support of the idea that body education (Physical Education) should be the starting point for the Stage Movement (The training of the body expression), first of all, but also for other disciplines of movement, included in the Actor's Art curriculum (pantomime, fencing, dance).
\end{abstract}

Key words: physical education, stage movement, body training

\section{Rezumat}

Disciplina intitulată "Pregătirea expresiei corporale" însumează acele activități care implică corpul și care vin în forme variate, atât ca structuri motorii, cât și ca trăsături funcționale. În cele ce urmează, vom încerca să aducem argumente în sprijinul ideii că educația corpului (Educația fizică) ar trebui să fie punctul de plecare pentru Mișcarea de scenă (Formarea expresiei corporale), în primul rând, dar și pentru alte discipline de mișcare, incluse în curriculumul Actorului (pantomimă, scrimă, dans).

Cuvinte cheie: educaţie fizică, mişcare, antrenament

\footnotetext{
${ }^{1}$ Lecturer, National University of Arts “George Enescu”, Iași,Romania, e-mail: analese2000@yahoo.com
} 


\section{Introduction}

We start from the clear definition given by Mihai Epuran: "By bodily activities we mean the physical education and sports activities. They are thus called because bodily exercise is the main and characteristic feature of these activities, which have ends in themselves" [1].

Physical education has been introduced into education at all levels, as a means of physical development and training, but also as an educational factor that ensures the efficiency of the entire training-educational process. In Theatre academic teaching, in addition to these goals, Physical Education also has the role of supporting the actor's development process by the means available to the Stage Movement.

Too few experts are concerned about the link between the Movement disciplines. Among them, few in number, we notice Professor Mihail Antonie from the Craiova University, the Faculty of Letters, the Department of Theatre Art, who discusses the state of the Movement disciplines in the course entitled the Training of the Bodily Expression. This is from where we have extracted details that make the transition from Physical Education and Sports to the Training of the bodily expression. The first valuable remark for the topic we are interested in is that: "The training of the bodily expression is a means of interdisciplinary approach of the physical education and sports movement in the artistic one" [2]. It is important to define the boundaries between Physical Education and the Stage Movement (the Training of the bodily expression), specifying the most important tasks of each discipline, and to keep in mind that Physical Education supports the psycho-physical training of the athlete and the actor.

The training of the bodily expression in the formative process aims at adapting the body exercises to the strictness of the conventional work on the stage. Exercises taken from Physical Education thus help the artistic interpretation necessary for the actor on his path to professional performance.

If the prior teaching task of The training of the bodily expression is "to develop the capacity to dialogue with the self and the body, as well as to develop communication skills through expressive, artistic movement" [2]. Physical education has the role of preparing the "instruments" that will be given in the harmony required by the stage movement.

\section{Experiment}

In order to simplify the argument, we use a practical experiment applied to students of the first year of acting. The experiment consists in acquiring an acrobatic element, sitting on the hands, through the algorithms (means and methods) of Physical Education:

- Sitting on the hands is an extremely difficult piece of acrobatic work, requiring a strain on both the arms and legs (present when pushing into the support leg while holding hands with the body leaned vertically). It is understood while carrying out this task, other muscle groups, mainly abdominal, and all the bones and organs are involved in the execution of that movement. The amplitude of the execution depends on the joint and muscular flexibility, but also the technique, aspects that acquired very faithfully during the Physical Education lessons. Once the acrobatic element has been appropriately mastered, the training of the bodily expression uses it in a more complex exercise, for example: sitting on the hands with the knees supported on the shoulder of the partner and lifting the torso. At this stage of the exercise, in which one is in the arms of his partner, with his knees bent over the partner's shoulders, the aesthetic and artistic elements are applied through different movements of arms, legs, grimaces, etc. In this way, the means of Physical Education prepare the acrobatic element in its natural form, and the training of the bodily expression will give it the artistic appearance.

In the following pictures (distributed in five stages), we present the element sitting on the hands in succession in order to obtain the composite element from the Stage Movement, starting from the basic element learned at Physical Education: 


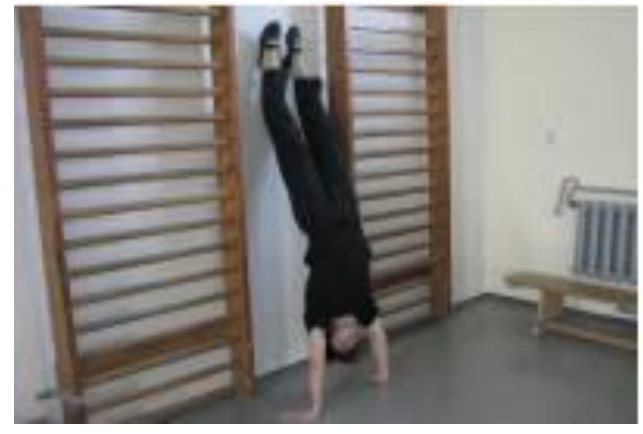

Fig.1. 1st stage

- the element sitting on his hands, appropriated in a pure physical state, at the Physical Education discipline

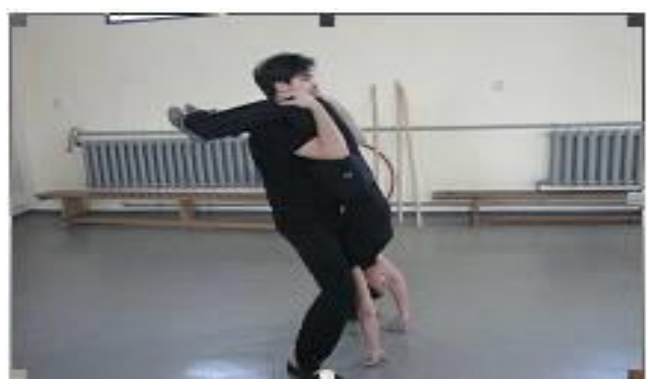

Fig.2. $2^{\text {nd }}$ stage

- is a variant of the first element, it is called "sitting on the hands with the support of $t$

Stages 3 and 4, "lifting the partner on the shoulders", involves elements of muscular force, mobility and aesthetic movement, combining the role of Physical Education with that of the Stage Movement, to achieve the final element.

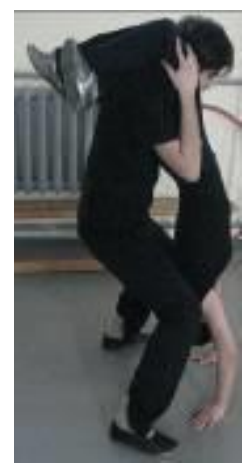

Fig.3. $3^{\text {rd }}$ stage

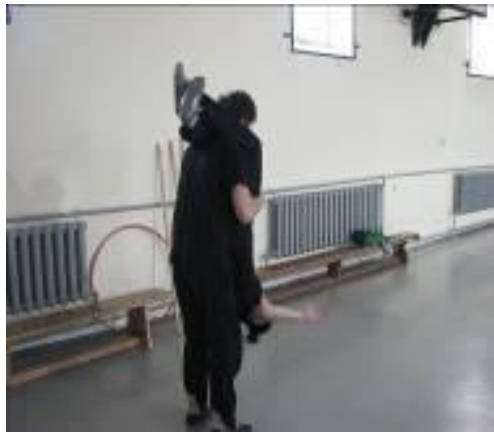

Fig.4. $4^{\text {th }}$ stage

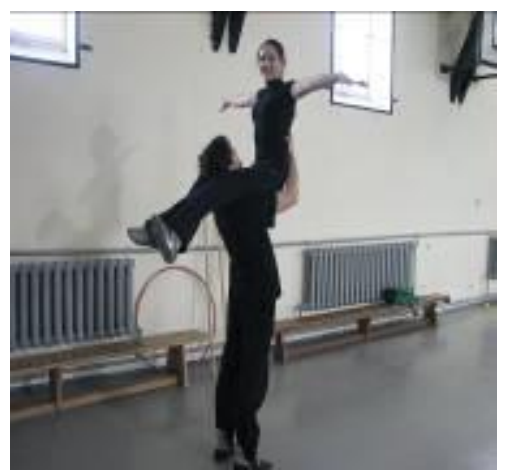

Fig.5. $5^{\text {th }}$ stage

The fifth stage is the final element required by the topics of the Stage Movement.

\section{Conclusions}

- At the origin of the exercises that sum up an acrobatic element is Physical Education, according to the following elements:

Physical education $\rightarrow$ Physical exercise $\rightarrow$ Acrobatic element $\rightarrow$ The training of the bodily expression

The training of the physical expression must and can work on a body already formed, in the sense of the presence of muscular force, necessary to execute certain elements required by this discipline, and the student-actor must be familiar with the working terms (for example: rolling forward and backward) but can also perform certain acrobatic elements.

Also, we present an example of acquiring a physical condition through the means of Physical Education, the student-actor being thus prepared to easily 
acquire the acrobatic elements by using the artistic means of the training of the bodily expression:

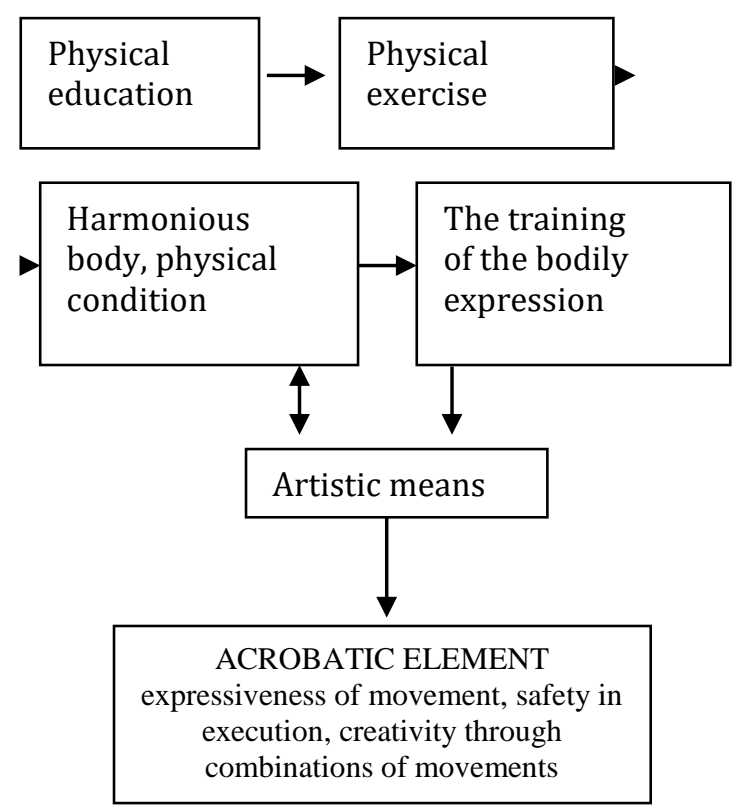

Scheme 1

The stage movement is not based only on the simple, natural and gymnastic exercises (according to the Romanian Dictionary, in terms of naturism and gymnastics) of Physical Education, but also targets other acrobatic movements, executed individually, in pairs or in groups, through which are established coordinates of complex communication, such as partner-partner, partnerobject or the most complex communication, with the viewers. However, acquiring the notions and means in the sphere of Physical Education by the students-actors assures an important operational capacity in educating the artistic spirit, constituting a developmental support in the thinking action for the formation of the expression and communication capacities, with which the future actor can argue convincing stage evolutions.

The training of bodily expression is a "means of educating the communication between the mind and the body, which will form a perfect symbiosis both for the motric and expressive aspect" [2]. By giving value to the physical exercise in various forms of practice (games, skill combinations etc.), Physical Education participates in the communication between mind and body, forming a connection between psychic and physical processes. But the expressive aspect is educated and imprinted through the training of the bodily expression. The following elements illustrates the collaboration between Physical Education and Stage Movement:

Physical Education + Stage Movement $=$ perfect symbiosis both motric and expressive

- The role of Physical Education in the university curriculum for Theatre is to familiarize the studentactor with physical exercise, skills and aptitudes in their "natural" state, following to receive the artistic specificity given to them by the other disciplines of motion. And the important goals of Physical Education in forming the actor must not be omitted: harmonious physical development; the acquisition and development of basic and applicative motor skills; cultivating love for movement; the formation of positive traits of will and character.

\section{References}

1. Epuran M. (1969). Activităţile corporale în lumina ştiinței educaţiei fizice şi sportului, in "Educaţie fizică şi sport", nr. 10, Bucharest.

2. Mihail A, (2005). Antrenamentul expresiei corporale. Curs, Universitaria Publishing House, Craiova. 